\title{
PENGARUH PERASAN MENGKUDU TERHADAP PERTUMBUHAN BAKTERI STAPHYLOCOCCUS AUREUS
}

\author{
Irmanita Wiradona $^{\varpi 1}$, Suwarsono $^{2}$, Lanny Sunarjo $^{3}$, Hermien Rimbyastuti ${ }^{4}$
}

\begin{abstract}
ABSTRAK
Penyebab penyakit gigi dan mulut terutama penyakit periodondal adalah bakteri Staphylococcus aureus. Upaya pencegahan salah satunya dengan bahan alam yaitu mengkudu. Mengkudu (Morinda citrifolia linn) mengandung antraquinon digunakan sebagai antibakteri. Tujuan penelitian ini adalah untuk mengetahui pengaruh konsentrasi larutan mengkudu (Morinda citrifolia linn) terhadap daya hambat pertumbuhan bakteri Staphylococcus aureus.

Penelitian ini menggunakan metode quasi experiment. Subyek penelitian dalam penelitian ini adalah bakteri Staphylococcus aureus. Penelitian ini menggunakan perasan mengkudu konsentrasi 40\%, $60 \%$ dan $80 \%$ dengan 3 kali pengulangan. Metode analisa data yang digunakan adalah deskriptif kuantitatif.

Hasil penelitian menunjukkan besar area daya hambat rata-rata perasan mengkudu dengan konsentrasi 40\% mempunyai rata-rata total diameter daya hambat sebesar 9,34 mm, konsentrasi $60 \%$ mempunyai rata-rata total diameter daya hambat sebesar 9,74 mm, konsentrasi $80 \%$ mempunyai rata-rata total diameter daya hambat sebesar 10,74 mm. Kesimpulan dari penelitian ini adalah rata-rata total diameter daya hambat yang paling besar yaitu pada konsnetrasi $80 \%$.
\end{abstract}

Kata Kunci : Perasan Mengkudu, Staphylococcus aureus

\begin{abstract}
Staphylococcus aureus is a bacterium causes of dental and oral diseases, especially periodontal disease. Efforts to prevent one of them with natural ingredients that Noni. Noni (Morinda citrifolia Linn) contains anthraquinone is used as an antibacterial. The purpose of this study was to determine the effect of concentration of noni (Morinda citrifolia Linn) on the inhibition of the growth of Staphylococcus aureus bacteria.

This is a quasi-experimental study. Research subjects bacterium Staphylococcus aureus. The study was conducted using a concentration of $40 \%, 60 \%$ and $80 \%$ respectively - each concentration done $3 x$ treatment. The data was analyzed with deskriptif kuantitatif.

The results showed a large area of inhibition of the average noni solution with a $40 \%$ concentration of 9.34, a 60\% concentration of 9.74, and the concentration of $80 \%$ by $10.74 \mathrm{~mm}$. The conclusion of this study is the average total diameter of inhibitation, most notably at a concentration of $80 \%$.
\end{abstract}

Keywords: Noni Juice, Staphylococcus aureus

\footnotetext{
$\overline{1,2,3,4)}$ Dosen Jurusan Keperawatan Gigi Poltekkes Kemenkes Semarang

$凶$ : irmanita.wiradona@gmail.com
} 


\section{PENDAHULUAN}

Penyakit gigi dan mulut yang menjadi masalah kesehatan masyarakat dalam hal ini adalah penyakit atau kelainan pada jaringan penyangga gigi dan karies gigi adalah penyakit yang diawali dengan proses demineralisasi yang disebabkan oleh suatu interaksi antara mikroorganisme, ludah, bagian-bagian yang berasal dari makanan dan email ( Houwink, 1993).

Penyakit periodontal merupakan masalah kesehatan gigi dan mulut yang memiliki prevalensi cukup tinggi di masyarakat dengan prevalensi penyakit periodontal pada semua kelompok umur di indonesia adalah 96,58\%. Menurut Riskesdas (Depkes 2008) prevalensi pengalaman penyakit periodontal di Indonesia menunjukkan banyak yang sudah terkena penyakit periodontal setidaknya pada kelompok usia 8 tahun yaitu 59,89\% dikota dan 59,67\% di desa pada kelompok usia 18 tahun sejumlah $72,44 \%$ dikota dan $93,44 \%$ di desa, dan pada kelompok usia 35-44 tahun sejumlah $88,67 \%$ di kota. Penyakit periodontal merupakan penyakit gigi dan mulut yang memiliki penyebab multifaktorial yaitu faktor sistemik, malnutrisi, obat-obatan dan utamanya disebakan oleh bakteri yang terakumulasi dalam plak gigi. Penyakit periodontal ini diawali dengan peradangan pada gusi apabila tidak dirawat akan bertambah parah. Keparahan penyakit periodontal tidak luput dari virulensi bakteri yang terakumulasi dalam plak gigi. Dari sekian banyak bakteri yang menyebabkan penyakit periodontal contohnya pada gingivitis salah satu bakterinya adalah Staphylococcus aureus (Howley, 2003).

Penyakit periodontal ini diawali dengan peradangan pada gusi apabila tidak dirawat akan bertambah parah. Keparahan penyakit periodontal tidak luput dari virulensi bakteri yang terakumulasi dalam plak gigi. Dari sekian banyak bakteri yang menyebabkan penyakit periodontal contohnya pada gingivitis salah satu bakterinya adalah Staphylococcus aureus (Howley, 2003).

Mengkudu (Morinda citrifolia) merupakan tanaman yang telah lama diketahui memiliki banyak khasiat tidak hanya untuk pengobatan namun juga untuk pencegahan berbagai penyakit. Buah mengkudu mengandung vitamin $\mathrm{C}$ dalam kadar tinggi, berbagai asam amino, protein, enzim, garam-garam mineral, dan sebagainya (Suprapti, 2005). Sejak lama diketahui pula bahwa tanaman mengkudu dapat digunakan antibakteri. Zat kimia yang terkandung diantaranya adalah damnacanthal, morindin, antraquinon, asam glutamat, asam askorbat, thiamin, glikosida dan skopoletin. Zat nutrisi yang terkandung dalam mengkudu diantaranya protein, mineral, vitamin yang berkhasiat sebagai antioksidan (Bangun \& Sarwono, 2002). Ekstrak buah mengkudu matang memiliki senyawa antibakteri terhadap Pseudomonas aeruginosa, $M$. pyrogenes, Salmonella typhosa, $S$. Montevideo, S. schottmuelleri, Shigella paradys, Eschericia coli, Staphylococcus aureus, Bacillus subtilis, Clostridium perfingens, dan Vibrio parahaemolyticus. Konsentrasi fenol 3000 ppm menunjukkan aktivitas bakteriostatik terhadap $S$. typosa dan Staphylococcus aureus (Damayanti dan Suparjana, 2007).

Tujuan penelitian ini untuk mengetahui pengaruh konsentrasi perasan mengkudu terhadap daya hambat bakteri Staphylococcus aureus.

\section{METODE PENELITIAN}

Penelitian ini merupakan quasi experiment (eksperimen semu) dengan rancangan "The One Shot Case Study" artinya perlakuan atau intervensi telah dilakukan kemudian dilakukan pengukuran (observasi) atau post test (Notoatmodjo, 2012). Dalam penelitian ini, melihat daya hambat bakteri Staphylococcus aureus sesudah mendapat perasan mengkudu dengan konsentrasi $40 \%, 60 \%$ dan $80 \%$. 
Populasi dalam penelitian ini adalah bakteri Staphylococcus aureus dalam media agar. Sampel yang digunakan $1 \mathrm{ml}$ suspensi bakteri Staphylococcus aureus.

Variabel pengaruh dalam penelitian ini perasan mengkudu dibuat dengan konsentrasi 40\%, 60\% dan 80\% dengan cara buah mengkudu setengah matang dicuci bersih lalu diparut. Kemudian diperas dan disaring diambil airnya. Setelah itu ditimbang dan diletakkan di dalam gelas ukur dan dicampur dengan aquades. Variabel Terpengaruh adalah Bakteri Staphylococcus aureus adalah bakteri yang ditumbuhkan pada suatu media PCA. Cara mengukur pertumbuhan bakteri adalah dengan mengukur daerah bebas bakteri yang disebut daerah oligodinamik (blank zone). Uji ini dilakukan pada permukaan media padat yaitu suspensi bakteri Staphylococcus aureus sebanyak $1 \mathrm{ml}$ yang dicampur dengan media PCA kemudian diberi kertas paper disc steril yang sudah dicelupkan kedalam larutan mengkudu dengan konsentrasi $40 \%, 60 \%$ dan $80 \%$. Setelah itu diinkubasi selama $1 \mathrm{x}$ 24 jam pada suhu $37^{0} \mathrm{C}$. Lalu dilihat diameter zona penghambatnya pada cawan petri, kemudian diukur dengan jangka sorong $(\mathrm{mm})$. Skala pengukuran yang digunakan adalah skala ratio.

Analisis Data dalam penelitian ini adalah deskriptif kuantitatif untuk mengetahui apakah ada pengaruh larutan mengkudu dalam konsentrasi 40\%, 60\% dan 80\%.

\section{HASIL PENELITIAN}

Tabel 1. Daya Hambat Perasan Mengkudu dengan Konsentrasi 40\%, 60\%, 80\% pada perlakuan ke-1

\begin{tabular}{|c|c|c|c|c|}
\hline \multirow{2}{*}{$\begin{array}{c}\text { Perlakuan } \\
\text { ke- }\end{array}$} & \multirow{2}{*}{$\begin{array}{l}\text { Radius } \\
\text { Oligodinamik } \\
(\mathrm{mm})\end{array}$} & \multicolumn{3}{|c|}{$\begin{array}{l}\text { Perasan Mengkudu } \\
\text { Konsentrasi }\end{array}$} \\
\hline & & $\begin{array}{l}40 \% \\
(\mathrm{X} 1)\end{array}$ & $\begin{array}{l}60 \% \\
(\mathrm{X} 2)\end{array}$ & $\begin{array}{l}80 \% \\
\text { (X3) }\end{array}$ \\
\hline \multirow{4}{*}{1} & Vertikal & 9,54 & 9,45 & 11,4 \\
\hline & Horisontal & 9,75 & 9,9 & 12,1 \\
\hline & Diagonal I & 9,33 & 10,58 & 11,35 \\
\hline & Diagonal II & 9,84 & 10,55 & 10,75 \\
\hline \multicolumn{2}{|r|}{ Total } & 38,46 & 40,48 & 45,60 \\
\hline \multicolumn{2}{|c|}{ Rata-rata } & 9,62 & 10,12 & 11,4 \\
\hline
\end{tabular}

Berdasarkan Tabel 1 diatas dapat dijelaskan bahwa hasil pengukuran pada perlakuan ke-1 rata-rata daya hambat perasan mengkudu yang paling besar adalah konsentrasi $80 \%$ sebesar $11,4 \mathrm{~mm}$. Sedangkan yang paling kecil adalah konsentrasi $40 \%$ sebesar 9,62 $\mathrm{mm}$.

Tabel 2. Tabel Daya Hambat Perasan Mengkudu dengan Konsentrasi 40\%, 60\%, 80\% pada perlakuan ke-2

\begin{tabular}{ccccc}
\hline \multirow{2}{*}{$\begin{array}{c}\text { Perlakuan } \\
\text { ke- }\end{array}$} & $\begin{array}{c}\text { Radius } \\
\text { Oligodinamik }\end{array}$ & \multicolumn{3}{c}{$\begin{array}{c}\text { Perasan Mengkudu } \\
\text { Konsentrasi }\end{array}$} \\
\cline { 3 - 5 } & $(\mathrm{mm})$ & $40 \%$ & $60 \%$ & $80 \%$ \\
& & $(\mathrm{X} 1)$ & $(\mathrm{X} 2)$ & $(\mathrm{X} 3)$ \\
& Vertikal & 8,85 & 9,53 & 9,25 \\
2 & Horisontal & 9,68 & 10,14 & 9,9 \\
& Diagonal I & 9,86 & 9,8 & 10,43 \\
& Diagonal II & 9,47 & 9,58 & 10,55 \\
\hline Total & 37,86 & 39,05 & 40,13 \\
\hline Rata-rata & 9,47 & 9,76 & 10,03 \\
\hline
\end{tabular}

Berdasarkan Tabel 2 diatas dapat dijelaskan bahwa hasil pengukuran pada perlakuan ke-2 rata-rata daya hambat perasan mengkudu yang paling besar adalah konsentrasi $80 \%$ sebesar $10,03 \mathrm{~mm}$. Sedangkan yang paling kecil adalah konsentrasi $40 \%$ sebesar 9,47 $\mathrm{mm}$.

Tabel 3. Tabel Daya Hambat Perasan Mengkudu dengan Konsentrasi 40\%, 60\%, 80\% pada perlakuan ke-3

\begin{tabular}{ccccc}
\hline \multirow{2}{*}{$\begin{array}{c}\text { Perlakuan } \\
\text { ke- }\end{array}$} & $\begin{array}{c}\text { Radius } \\
\text { Oligodinamik } \\
\end{array}$ & \multicolumn{3}{c}{$\begin{array}{c}\text { Perasan Mengkudu } \\
\text { Konsentrasi }\end{array}$} \\
\cline { 3 - 5 } & & $40 \%$ & $60 \%$ & $80 \%$ \\
& Vertikal & $(\mathrm{X} 1)$ & $(\mathrm{X} 2)$ & $(\mathrm{X} 3)$ \\
3 & Horisontal & 8,42 & 8,5 & 10,6 \\
& Diagonal I & 9,41 & 9,5 & 11,13 \\
& Diagonal II & 9,13 & 9,46 & 10,8 \\
& Total & 35,81 & 37,33 & 10,45 \\
\hline Rata-rata & 8,95 & 9,33 & 10,74 \\
\hline
\end{tabular}

Berdasarkan Tabel 3 diatas dapat dijelaskan bahwa hasil pengukuran pada perlakuan ke-1 rata-rata daya hambat perasan mengkudu yang paling besar adalah konsentrasi $80 \%$ sebesar $10,74 \mathrm{~mm}$. Sedangkan yang paling kecil adalah konsentrasi $40 \%$ sebesar $8,95 \mathrm{~mm}$. 
Tabel 4. Tabel Rata-Rata Total Daya Hambat Perasan Mengkudu dengan Konsentrasi $40 \%, 60 \%, 80 \%$

Rata-rata Diameter Daerah Hambat (mm) Perasan Mengkudu terhadap

\begin{tabular}{cccc}
\multirow{2}{*}{ Perlakuan } & \multicolumn{3}{c}{ Bakteri Staphylococcus mutans } \\
\cline { 2 - 4 } & $40 \%$ & $60 \%$ & $80 \%$ \\
& $\mathrm{X} 1$ & $\mathrm{X} 2$ & $\mathrm{X} 3$ \\
\hline Perlakuan Ke-1 & 9,62 & 10,12 & 11,4 \\
Perlakuan Ke-2 & 9,47 & 9,76 & 10,03 \\
Perlakuan Ke-3 & 8,95 & 9,33 & 10,74 \\
\hline Rata-rata total & 9,34 & 9,74 & 10,72 \\
\hline
\end{tabular}

Berdasarkan Tabel 4 di atas dapat dijelaskan bahwa rata-rata total daya hambat terhadap pertumbuhan bakteri Staphylococcus aureus pada perasan mengkudu tertinggi adalah $10,72 \mathrm{~mm}$ pada konsentrasi $80 \%$. perasan mengkudu dengan konsentrasi $60 \%$ sebesar $9,74 \mathrm{~mm}$, dan ratarata total daya hambat terhadap pertumbuhan bakteri Staphylococcus aureus pada perasan mengkudu terendah adalah $9,34 \mathrm{~mm}$ yaitu pada konsentrasi $40 \%$.

Perasan mengkudu dengan konsentrasi 40\%, 60\% dan 80\% mempunyai efek menghambat terhadap bakteri Staphylococcus aureus. Efek menghambat yang dimiliki pada perasan mengkudu terjadi karena mengkudu mengandung senyawa fenolik, yaitu tannin dan flavonoid yang merupakan anti oksidan primer. Efek menghambat mengkudu berkaitan dengan senyawa fenol yang dikandungnya. Senyawa fenol mampu mendenaturasi protein dan mengganggu fungsi membran sel sehingga sel menjadi lisis (Jawetz et.al., 2005).

Staphylococcus aureus merupakan bakteri Gram positif. Sufiriyanto dan Indraji (2005) menyatakan bakteri Gram positif tidak tahan terhadap senyawa fenol dan antraquinon. Senyawa fenol dan antraquinon dari buah mengkudu menekan pertumbuhan bakteri Gram positif karena kemampuan penetrasi senyawa ini dalam dinding sel bakteri. Senyawa fenol dan antraquinon termasuk senyawa yang larut lemak. Golongan fenol mampu merusak membran sel, menginaktifkan enzim dan mendenaturasi protein sehingga dinding sel mengalami kerusakan karena penurunan permeabilitas. Perubahan permeabilitas membran sitoplasma memungkinkan terganggunya transportasi ion-ion organik yang penting ke dalam sel sehingga berakibat terhambatnya pertumbuhan bahkan hingga kematian sel (Damayanti dan Suparjana, 2007). Dalam konsentrasi tinggi, kandungan fenol menembus dan mengganggu dinding sel bakteri dan mempresipitasi protein dalam sel bakteri. Dalam konsentrasi yang lebih rendah, fenol menginaktifkan sistem enzim penting dalam sel bakteri (Oliver et al., 2001).

Pada beberapa konsentrasi yang digunakan memperlihatkan zona hambat bakteri untuk setiap konsentrasi mengkudu. Peningkatan konsentrasi perasan mengkudu dari $40 \%$, 60\% dan $80 \%$ terdapat perbedaan daya hambat, pada perasan mengkudu $80 \%$ mempunyai daya hambat lebih baik dari 40\%. Hal ini sesuai dengan Pelcter dan Chan (1988) bahwa semakin tinggi konsentrasi suatu bahan antibakteri maka aktivitas antibakterinya semakin kuat pula. Dengan semakin tinggi konsentrasi larutan mengkudu maka kandungan zat antibakteri juga semakin banyak (Efri dan Praseyto, 2004).

Pada peningkatan konsentrasi dari $40 \%$ ke $60 \%$ dan $60 \%$ ke $80 \%$ apabila dibandingkan diameter zona hambat bakteri, daya hambat larutan mengkudu terhadap bakteri Staphylococcus aureus tidak terlalu besar. Meskipun terdapat peningkatan rerata diameter zona hambat sesuai peningkatan konsentrasi. Diameter zona terang larutan mengkudu termasuk dalam kategori lemah. Pada umumnya diameter zona hambat cenderung meningkat sebanding dengan mengingkatnya konsentrasi larutan.

Perasan mengkudu bekerja tidak stabil pada penghambatan, ini ditunjukkan dengan konsentrasi yang semakin besar tidak memberikan penghambatan yang lebih besar. Kemungkinan karena larutan mengkudu merupakan ekstrak kasar yang kelarutan senyawa antibakterinya belum maksimal, sehingga aktivitasnya tidak maksimal pula (Dewi, 2010). Selain itu pada proses pembuatan larutan mengkudu, mengkudu 
diambil dengan cara diparut kemungkinan mengurangi efek zat antibakteri yang terdapat pada mengkudu mengakibatkan pengaruh penghambatan pertumbuhan bakteri Staphylococcus aureus menurun. Perbedaan daya hambat bakteri kemungkinan dipengaruhi oleh faktor bahan organik asing yang masuk pada cawan petri pada saat memasukkan suspensi bakteri Staphylococcus aureus sehingga akan menurunkan daya hambat perasan buah mengkudu. Menurut Greenwood (1995), penggabungan antara zat antimikroba dan bahan organik asing akan membentuk zat antimikroba berupa endapan sehingga zat antimikroba tidak lagi mengikat organisme dan akumulasi bahan organik terjadi pada permukaan sel mikroorganisme sehingga terjadi perlindungan yang mengganggu kontak antar zat mikroba dan mikroorganisme. Faktor lainnya adalah jenis dari mikroorganisme itu sendiri, karena setiap mikroorganisme memiliki ketahanan yang berbeda-beda terhadap suatu bahan tertentu. Jadi ada kemungkinan apabila bakteri jenis Staphylococcus aureus ini memiliki ketahanan yang cukup baik dengan bahan mengkudu sehingga daya hambat yang dihasilkan kurang maksimal. Kualitas, usia dari buah mengkudu juga dapat mempengaruhi besarnya daya hambat bakteri yang dihasilkan.

\section{KESIMPULAN}

Berdasarkan hasil penelitian yang telah dilakukan di laboratorium mikrobiologi, diperoleh kesimpulan sebagai berikut:

1. Perasan mengkudu memiliki efek menghambat pertumbuhan bakteri Staphylococcus aureus dengan rata-rata zona hambat pertumbuhan bakteri yaitu konsentrasi $40 \%$ sebesar 9,34 $\mathrm{mm}$, konsentrasi $60 \%$ sebesar $9,74 \mathrm{~mm}$, dan konsentrasi $80 \%$ sebesar $10,72 \mathrm{~mm}$. Pada konsentrasi 40\%, 60\% mempunyai daya hambat sangat lemah sedangkan pada konsentrasi $80 \%$ daya hambat bakteri lemah.

2. Perasan mengkudu yang paling berpengaruh dalam menghambat pertumbuhan bakteri Staphylococcus aureus yaitu perasan dengan konsentrasi $80 \%$ mempunyai daya hambat pertumbuhan bakteri dengan hasil paling besar yaitu 10,72.

\section{SARAN}

1. Hasil penelitian ini bisa menjadi acuan untuk lebih mempotensialkan perasan mengkudu khususnya di bidang kesehatan gigi dan mulut karena perasan mengkudu terbukti dapat menghambat pertumbuhan salah satu bakteri patogen di dalam rongga mulut yaitu Staphylococcus aureus.

2. Perlu penelitian lanjutan dengan tingkat kematangan mengkudu yang berbeda. Bisa juga dengan konsentrasi larutan mengkudu yang berbeda atau kombinasi dengan bahan laian mengingat rasa mengkudu yang pahit mungkin kurang diminati masyarakat meskipun sudah terbukti mengkudu mampu menghambat bakteri patogen dalamrongga mulut.

\section{DAFTAR PUSTAKA}

Bangun, A.P. \& Sarwono, B. 2002. Khasiat \& Manfaat Mengkudu. Tangerang: Agro Media

Damayanti, E. dan T. B. Suparjana. 2007. Efek penghambatan beberapa fraksi ekstrak buah mengkudu terhadap Shigella dysenteriae. Prosiding Seminar Nasional Tehnik Kimia Kejuangan. Fakultas Biologi Universitas Jenderal Soedirman. Yogyakarta.

Depkes RI .(2008). Profil Kesehatan Masyarakat. Depkes RI, Jakarta. 
Dewi FK. 2010. Aktivitas antibakteri ekstrak etanol buah mengkudu (Morinda citrifolia, L) terhadap bakteri pembusuk daging segar. Skripsi. Surakarta: Fakultas Matematika dan Ilmu Pengetahuan Alam Universitas Sebelas Maret; p. 26.

Erfi dan Prasetyo, J. 2005. Efek Penghambatan Ekstrak Mengkudu Terhadap Pertumbuhan Patogen dan Perkembangan Penyakit Antraknosa (Colletotrichum capsici) pada Tanaman Cabe. Program Penelitian Dosen Mu Universitas Lampung

Greenwood, Stall R, Paul J, 1995. Medical Microbiology. ELBS; Hongkong Houwink. B,1993, IlmuKedokteran Gigi danPenegahan. Yogyakarta : Gajah Mada University Press.

Howley,L.2003.

IntisariMikrobiologidanpenyakitinfeks $i$. Jakarta: Hipokrates.

Jawetz, E., J.L. Melnick., E.A. Adelberg., G.F. Brooks., J.S. Butel., dan L.N. Ornston. 2005. Mikrobiologi Kedokteran. Edisi ke-20 (Alihbahasa :Nugroho\&R.F.Maulany).Jakarta : Penerbit Buku Kedokteran EGC. Hal 211,213,215.

Notoatmodjo,S., 2012. Metodologi Penelitian Kesehatan. Jakarta: PT. RinekaCipta.

Oliver, S. P., B. E. Gillespie, M. J. Lewis, S. J. Ivey, R. A. Almeida, D. A. Luther, D. L. Johnson, K. C. Lamar, H. D. Moorehead and H. H. Dowlen. 2001. Efficacy of a new premilking teat disinfectant containing a phenolic combination for the prevention of mastitis. J. Dairy Sci. 84: 1545-1549.
Pelczar, M.J.dan Chan, E. C. S. 1988. Dasardasar Mikrobiologi . Universitas Indonesia. Jakarta

Sufiriyanto dan M. Indraji. 2005. Uji in vitro dan in vivo ekstrak campuran mengkudu (Morinda citrifolia) dan bawang putih (Allium sativum) pada sapi perah penderita mastitis sub klinis. J. Anim. Prod. 7: 101-105.

\section{Suprapti, M., L. 2005. Aneka Olahan Mengkudu Berkhasiat Obat. Yogyakarta: Kanisius}

